\title{
A NEW SPECIES OF UTRICULARIA SECT. ORCHIDIOIDES (LENTIBULARIACEAE) FROM THE AMOTAPE-HUANCABAMBA ZONE OF NORTHERN PERU
}

\author{
Tilo Henning $^{1}$ (D), Joshua P. Allen ${ }^{2}$ iD \& Eric F. Rodríguez Rodríguez ${ }^{3}$
}

\author{
${ }^{1}$ Leibniz Centre for Agricultural Landscape Research (ZALF), Eberswalder Str. 84, 15374, Müncheberg, Germany; \\ HenningTilo@web.de (author for correspondence). \\ ${ }^{2}$ Comunidad Campesina Maska S/N, Pisac, Peru. \\ ${ }^{3}$ Herbarium Truxillense (HUT), Universidad Nacional de Trujillo, Jr. San Martín 392, Trujillo, Peru.
}

\begin{abstract}
Henning, T.; J. P. Allen \& E. F. Rodríguez Rodríguez. 2021. A new species of Utricularia Sect. Orchidioides (Lentibulariaceae) from the Amotape-Huancabamba Zone of North Peru. Darwiniana, nueva serie 9(2): $299-311$.

A new species of Utricularia Section Orchidioides: Utricularia amotape-huancabambensis sp. nov. (Lentibulariaceae), endemic to Northern Peru is described and illustrated. It is known from two populations so far, both located in the Province Bongará, Dpto. Amazonas at ca. $2200 \mathrm{~m}$ altitude. The new species inhabits the páramo of the low white sandstone plateaus, an extension of the southern branches of the Condor mountain range in the southeastern part of the Amotape-Huancabamba phytogeographic zone. A diagnosis, description, etymology and an identification key covering the Andean and selected similar species of the section are presented. The distribution, habitat, ecology, associated flora, preliminary conservation status, an observed hybridization with sympatric $U$. unifolia and the affinities of the new species with other related taxa are discussed. The new species is known from two close-by populations in the same region and likely affected by anthropic pressure. Threatening changes in land use, resulting in habitat fragmentation or loss or changing water regimes in the course of climate change will have severe consequences for the sensitive páramo ecosystem and thus the populations of U. amotapehuancabambensis. Therefore, this new spectacular species of Utricularia is preliminarily considered Critically Endangered (CR).
\end{abstract}

Keywords. Andes mountain range; carnivorous plant; climate change; endemism; taxonomy.

Resumen. Henning, T.; J. P. Allen \& E. F. Rodríguez Rodríguez. 2021. Una nueva especie de Utricularia sect. Orchidioides (Lentibulariaceae) de la Zona Amotape-Huancabamba del Norte de Perú. Darwiniana, nueva serie 9(2): 299-311.

Se describe e ilustra una especie nueva de Utricularia Sección Orchidioides a U. amotapehuancabambensis sp. nov. (Lentibulariaceae), endémica al norte de Perú. Hasta el momento, se conocen dos poblaciones de este nuevo taxón localizadas en la provincia Bongará, Dpto. Amazonas a $2200 \mathrm{~m}$ de altitud en el páramo de las mesetas bajas de arenisca blanca, una continuación de los ramales sureños de la cordillera del Cóndor en el sur-este de la zona fitogeográfica de Amotape-Huancabamba. Se presenta la diagnosis, descripción, etimología y una clave de identificación de las especies andinas y similares de la sección. Se discuten la distribución, el hábitat, la ecología, la flora asociada, el estado de conservación preliminar y la relación con sus afines, en particular con la especie simpátrica U. unifolia con quien además se observó una hibridación. Utricularia amotape-huancabambensis es conocida por dos poblaciones restringidas en la misma región y probablemente es afectada por la acción antrópica, referida al cambio de uso del suelo, la fragmentación y la pérdida de hábitat, así como por cambios en los regímenes hídricos en el curso del cambio climático. En todos los casos, habrá graves consecuencias para el ecosistema frágil de páramo y las poblaciones de la nueva especie. Por consiguiente, es considerada preliminarmente En Peligro Crítico (CR).

Palabras clave. Cambio climático; cordillera de los Andes; endemismo; planta carnívora; taxonomía. 


\section{INTRODUCTION}

The genus Utricularia L. is the largest within the Lentibulariaceae family (Lamiales) and, together with Drosera L. (Droseraceae, Caryophyllales), is the most speciose carnivorous plant group (Fleischmann, 2015). Utricularia can be found almost worldwide in all suitable aquatic and terrestrial habitats with distribution concentrations in the Neotropics and Australia (Taylor, 1989). The infrageneric classification as established by Taylor in his seminal monograph (1989) has since been only slightly altered in the course of molecular studies (Jobson et al., 2003; Müller \& Borsch, 2005) and most of the sections revised could be retrieved as natural groups and constitute well circumscribed monophyla (Müller \& Borsch, 2005; Rodrigues et al., 2017).

Although many new species have been described in the last decades (Fleischmann, 2012, 2015), constantly expanding the taxonomic extent of the genus to date (Gonella et al., 2020; Cheng et al., 2021), its infrageneric classification, however, largely remained stable. One exception is the neotropical section Orchidioides A. DC., whose definition has been altered by the recent reinclusion of the taxa previously considered under section Iperua P. Taylor (Taylor, 1986, 1989), based on molecular and morphological evidence (Müller \& Borsch, 2005; Rodrigues et al., 2017). The latest taxonomic additions to the section are U. uxoris Gómez-Laur. (Gómez-Laurito, 2005) from Costa Rica and $U$. cornigera Studnička (Studnička, 2009), whose status as a valid species could recently be verified after a hybridogenous origin had been debated (Rodrigues et al., 2017). The section as currently defined contains 16 species of terrestrial or epiphytic plants and is restricted to the Neotropics. Most of these taxa have ornamental flowers that resemble those of showy orchid-species and are amongst the largest in the whole genus ( $U$. humboldtii R.H. Schomb., U. alpina Jacq., U. praetermissa P. Taylor, $U$. nelumbifolia Gardner and $U$. cornigera). However, overall plant and flower size varies greatly within the section. Utricularia sect. Orchidioides is furthermore characterized by usually simple, elongated or rarely reniform to peltate leaves and the presence of tubers to survive drier periods in dormancy, two convergent characteristics that underline their superficial similarity with many epiphytic orchids with simple leaves and pseudobulbs as storage organs. Species of section Orchidioides are usually rather widespread and occur along a considerable longitudinal and/or latitudinal distributional range. Most of them are found throughout Central America (including the Antilles) and northern South America. Only a few species show an Andean distribution (e.g. $U$. praetermissa, U. endresii Rchb.f.) and only U. asplundii P. Taylor, U. unifolia Ruiz \& Pav. and $U$. jamesoniana reach further south into the central and southern Andes (Fig. 1). The moist slopes of the eastern Andes provide a continuum of suitable habitats with enough precipitation, allowing a considerable latitudinal distribution of these taxa from Ecuador to Bolivia.

Utricularia jamesoniana and $U$. asplundii are small to medium sized, strictly epiphytic species that have been reported from several Peruvian departments but are usually not very abundant. Utricularia unifolia Ruiz \& Pav. is much more common and is, up until now, the largest species of Utricularia in Peru. With its attractive lavender to violet, medium-sized flowers (Fig. 2), it has been reported from many eastern Andean regions in several departments (Fig. 1) and is amply documented in national and international herbaria and online databases. Interestingly, despite its frequency in collections, U. unifolia has so far not been included in molecular studies of any scope. It is found either growing epiphytically on trunks of treeferns or on moss-covered rocky slopes in the cloud-forest belt. This distinct species is relatively common on humid slopes of the Andes facing Amazonia and shows only little morphological variation even between distant populations (pers. obs.).

During fieldwork in cloud forest remnants in the province of Bongará, in the Department of Amazonas, close to the border of San Martín (northern Peru) in January 2020, in close proximity to typical stands of flowering $U$. unifolia, vegetative individuals with strikingly different leaves and distinct morphology were found. The differences in leaf shape and overall size made it clear that this was an undescribed species of Utricularia. 


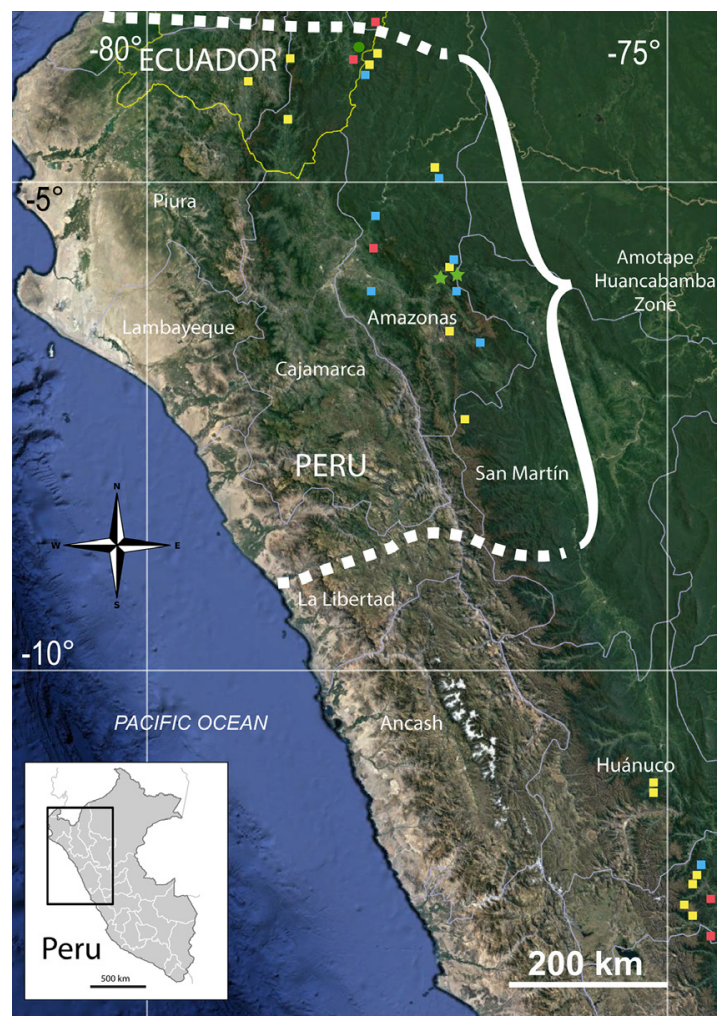

Fig. 1. Distribution of Utricularia sect. Orchidioides in the Amotape-Huancabamba Zone and adjacent Central Peru. Green stars, U. amotape-huancabambensis. Yellow squares, U. unifolia. Blue squares, U. jamesoniana. Red squares, $U$. asplundii. Green circle, $U$. cf. amotapehuancabambensis (Pérez et al. 7423, QCA). Color version at http://www.ojs.darwin.edu.ar/index.php/darwiniana/ article/view/955/1230

The place was later revisited by J. P. Allen in March 2020 and a second population with flowering specimens was discovered. Hence, Utricularia amotape-huancabambensis sp. nov. is here described as new to science. Its distribution and habitat characteristics, including the local flora composition is presented. The new taxon is illustrated and its ecological requirements and adaptations as well as its affinities are discussed. A preliminary conservation status is proposed and the significance of this surprising and relevant addition to the Peruvian flora, discovered in an otherwise relatively well-known and easily accessible area, is emphasized.

\section{MATERIALS AND METHODS}

Morphological data was initially measured solely on the type material. In search for additional and potentially overlooked material, the following Peruvian and other herbaria were consulted: CPUN, CUZ, F, HAO, HOXA, MO, PRG, USM, QCA(Thiers, 2021). This search yielded no unambiguous additional collections of the new species. The type locality was visited repeatedly and photographs and additional data were taken in situ to record intraspecific morphological variation, however no additional herbarium material was collected. Vegetative organs (leaves, petiole, floral peduncle, tubers and traps) and reproductive organs (flowers and fruits) were collected and preserved in liquid (70\% ethyl alcohol or AFA), the liquid material was later dried and added to the paratype specimen. Micromorphology was studied using a stereoscope (Motic SMZ-140) and stereomicroscope (Olympus CX22). The morphological description and its terminology follow Taylor (1989). For the distribution map of the species of sect. Orchidioides native to Peru, the following online databases were consulted and data was completed with authors' personal field observations: gbif.org, tropicos.org, inaturalist.org, atrium.andesamazon.org, collectionsbotany.fieldmuseum.org.

\section{TAXONOMIC TREATMENT}

Utricularia amotape-huancabambensis sp. nov.

T. Henning, E. Rodr. \& J.P. Allen. TYPE: Perú, Amazonas, Bongará, pajonales de arena blanca, hierba unifolia con bulbos transparentes y rizomas entre los musgos, con flores color blanco con dos líneas amarillas en el centro, $2200 \mathrm{~m}$ s.m., 6-III2020, J. P. Allen \& L. Rimarachin C. 1 (holotype HUT-60473). Figs. 2 A-D, F; 3 A-B, G-M and 4.

\section{Diagnosis}

Utricularia amotape-huancabambensis belongs to Utricularia section Orchidioides and is closely related to $U$. unifolia. It differs from it by having a more robust habit, a broadly ovate to rounded leaf lamina, longer petioles and inflorescences, much larger flowers with a white or slightly lavender corolla and an upper lip slightly longer and wider than the calyx. The spur is terminally curved downwards. 


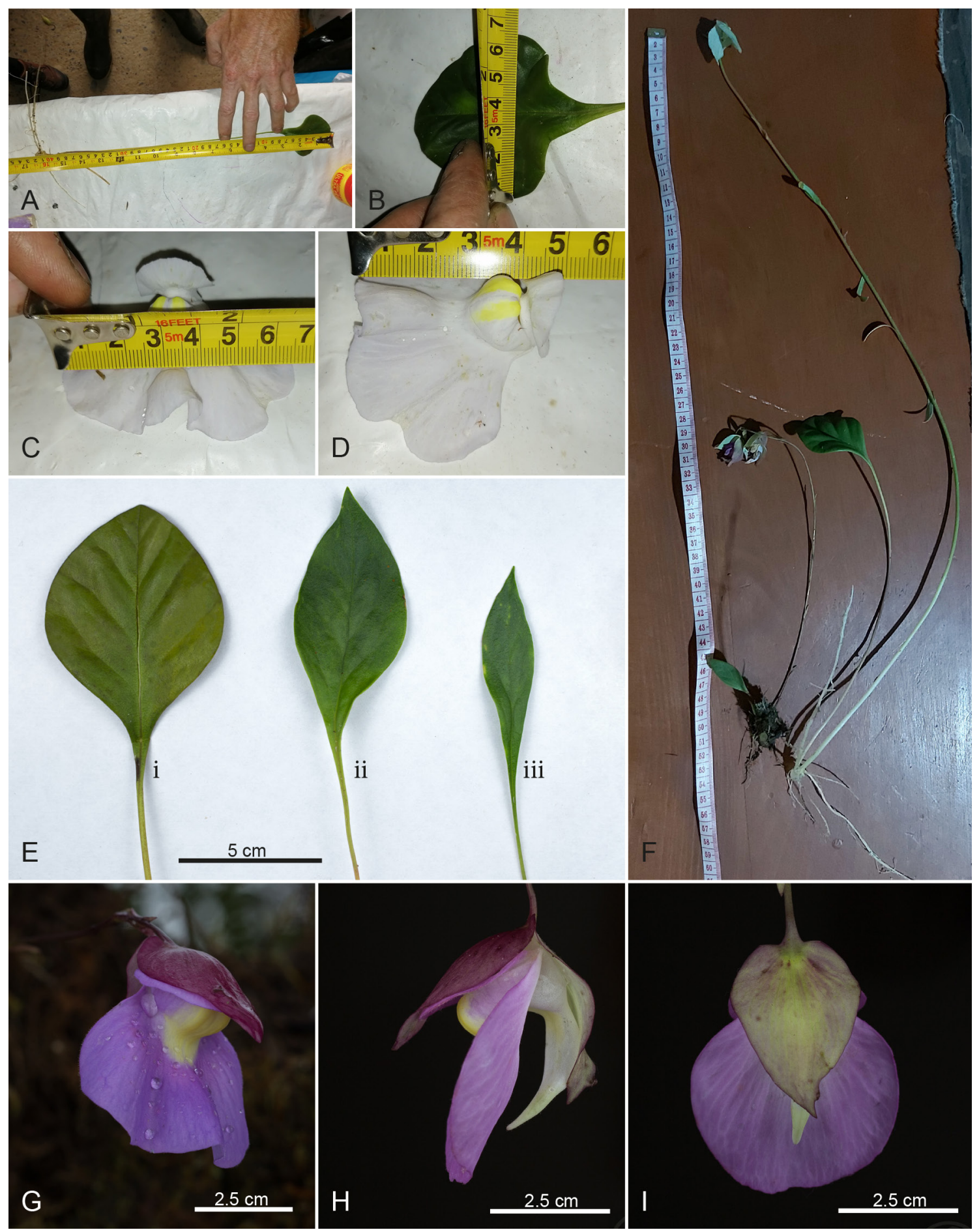

Fig. 2. Utricularia amotape-huancabambensis. A, leaf with petiole. B, leaf lamina. C, flower width. D, flower length. E, leaves of U. amotape-huancabambensis (i), a potential hybrid (ii) and U. unifolia (iii) from the same locality. F, comparison of adult plants of the two species. G-I, flower of $U$. unifolia, with the typical narrower, violet corolla and the single-bend spur. All photographs by J. P. Allen. Color version at http://www.ojs.darwin.edu.ar/index.php/darwiniana/article/view/955/1230 


\section{Description}

Terrestrial herb, relatively robust, perennial, up to $80 \mathrm{~cm}$ tall. Rhizoids absent. Stolons few, linearfiliform, loosely branched, irregularly spaced branches, up to $50 \mathrm{~cm}, 0.5-1 \mathrm{~mm}$ diam. Tubers ellipsoid, translucent, attached just below petioles and peduncles or attached sparsely on stolons, single or in pairs, up to $1 \mathrm{~cm}$ diam. Leaves 1-2 from the peduncle base, long-petiolate, petioles terete, slightly grooved at the base of the lamina, $24-40 \mathrm{~cm}, 1-1.5 \mathrm{~mm}$ diam., the lamina broadly ovate to rounded, glabrous, margin entire, sometimes slightly sinuous, with the base acutely cuneate to long attenuated, sometimes asymmetrical, and apex slightly acute to obtuse, mostly 5-7.5 $\times$ 4.1-6.5 cm, 0.8-1 mm thick, multi-veined, coriaceous, brittle. Traps numerous on capillary stolon branches, globose, subsessile, $0.5-1 \mathrm{~mm}$ diam., the mouth basal with two reflected dorsal subulate appendages. All vegetative parts, leaf veins, petiole bases and flower peduncles, tubers and traps covered with scattered globose-cylindrical glands. Inflorescence erect or spreading, 40-80 cm, solitary; peduncle terete, glabrous, $1.5-2.2 \mathrm{~mm}$ diam. The scales usually sparse, sessile, generally narrowly elliptical, often falcate, acute, $3-4 \times 0.6-0.8 \mathrm{~cm}$. Bracts similar to the scales, $3-4 \mathrm{~cm}$, but often slightly wider, 0.6-1 cm wide. Bracteoles usually somewhat smaller than the bract, up to $1.5-2 \mathrm{~cm}$. Flowers 1-3, the raceme lax, with the internodes $3-3.5 \mathrm{~cm}$; pedicels filiform, narrow-winged, 2-2.5 cm. Calyx lobes subequal, widely ovate, with the base slightly cordate and the apex acute, greenish-purple, multi-veined, 2.3-3 × 1.6-2.1 cm. Corolla 4-6 × (4-) 5-7 (-8) cm, white or slightly lavender with two elongated yellow spots at the base of the lower lip, sparsely stipitateglandular; upper lip ovate, with rounded apex, the basal sac with a distinctive raised marginal rim, slightly longer and wider than the calyx; lower lip limb subcircular in outline, the base with a conspicuous rounded swelling, the apex rounded or retuse, irregularly lobed; palate with a pubescent, slightly raised, marginal rim; spur subulate, white, about as long as, or longer than the lower lip, located in a long cavity, curved upwards towards the lower lip, apex acute, turned downwards. Filaments 2, curved, thickened at the apex, 4-5 $\mathrm{mm}$, the anther thecae distinct. Ovary globose, 2-2.5 mm diam.; style short, thick, 1.5-2 mm; stigma lower lip quadrate, the upper lip much smaller, deltoid. Fruit not seen.

\section{Etymology}

The name refers to the Amotape-Huancabamba Zone, the area around the Huancabamba depression, a partial interruption of the Andean mountain range by the Chamaya river drainage system, which occupies large parts of northernmost Peru and the southern tip of Ecuador (Fig. 1). The mosaic landscape in this region is characterized by a remarkable diversity in different habitat types and a corresponding exceptional zoo- and phytodiversity. In particular, the high rate of narrow endemism concentrated in this relatively small area is intriguing and has led to the idea to consider this area a phytogeographical zone of its own right (such as e.g. the Capensis). "A sizable part of Andean biodiversity seems to be concentrated into this relatively small area, which makes effective protection of the diverse habitats of this zone a high priority" (Weigend, 2002). The name of this new species has been chosen to reinforce this demand and encourage Peru and Ecuador to intensify the urgent conservation efforts for the remaining habitats in this otherwise highly fragmented landscape. Both climate change and urban sprawl are massive threats especially to the remaining forest patches. They are home to an unparalleled diversity of flora and fauna, the known extent of which is here complemented by this emblematic species of flowering plant. The name is intended to serve as a hortatory reminder of the unabated destruction of irreplaceable biodiversity in areas such as the Amotape-Huancabamba Zone (Karger et al., 2021) that are both: heavily overexploited while still underexplored.

\section{Affinities}

The new species is closely allied to other Andean Utricularia from section Orchidioides, in particular to sympatric (syntopic) U. unifolia. Initial considerations that it might be an aberrant local form of $U$. unifolia were rejected due to the considerable and consistent differences in leaf and flower morphology and overall size of the plants (Figs. 2, 3). Utricularia unifolia is widespread, well documented and a "quite distinct species" (Taylor, 1989: 124), although morphological variation to a lesser extent has been reported (Taylor, 1989; pers. obs.). 


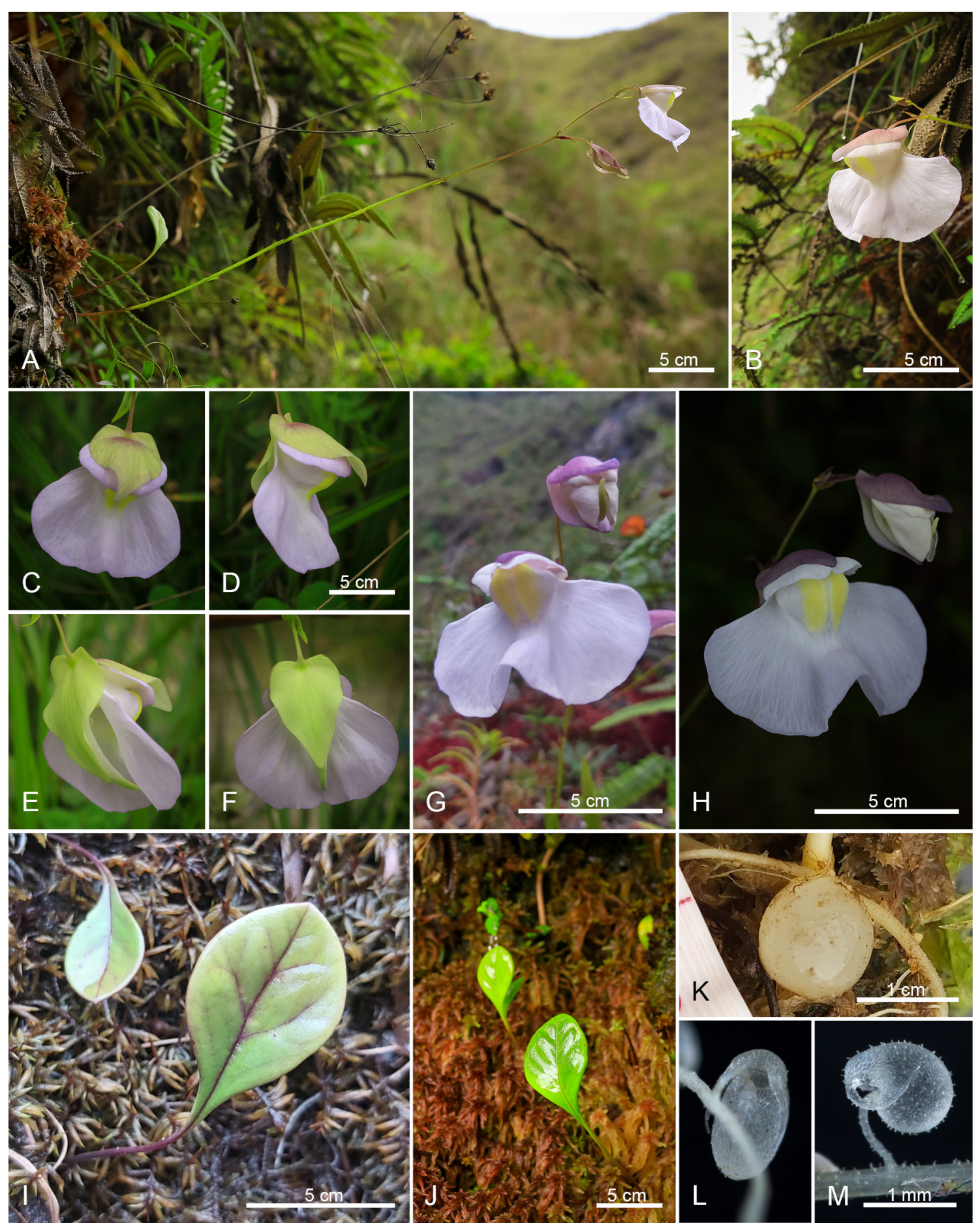

Fig. 3. Utricularia amotape-huancabambensis. A, flowering plant, growing fully exposed to sunlight with upwardsbended, shield-like leaf. B, ditto, flower in front-lateral view. C-F, flower of a plant growing in the shade with thinner corolla and greenish calyx. G-H, inflorescence of the typical form. I-J, leaves growing out of the moss cushions. K, tuber. L, utricle, frontal view. M, utricle, lateral view. All photographs by J. P. Allen. Color version at http://www.ojs. darwin.edu.ar/index.php/darwiniana/article/view/955/1230 
Remaining doubts were allayed after the discovery of hybrid individuals in syntopic populations of $U$. unifolia and $U$. amotapehuancabambensis. These hybrid plants represent morphological intermediate individuals and indicate a secondary contact of the two taxa. The presence of hybrids underlines the distinctiveness of the new taxon and therefore its status as a valid species, as well as its clear affinity to $U$. unifolia as the potential closest sister taxon.

Putative deciduous (Taylor, 1989) Utricularia endresii, that occurs from Central America to Ecuador, also has large, lavender to whitish flowers and has been reported to ascend into similar altitudes at its southern distribution limit in Ecuador. However, it is characterized by a dense glandular corolla, a leaf morphology and texture similar to that of $U$. unifolia (narrowly oblong and thin, membranous when dried; Taylor, 1989) and is supposed to be adapted to (seasonally) drier habitats where it loses its foliage to survive the dry season in dormancy. It cannot be confused with the new species and any other Andean Utricularia. Also, $U$. amotape-huancabambensis shows some similarity to $U$. praetermissa from Central America. Both species share the basic flower morphology with double-curved spurs and a usually white corolla. Furthermore, the leaves of both species show a prominent venation and are relatively thick compared with those of other members of the section Orchidioides sensu Taylor (1989). These characters are shared with $U$. unifolia, indicating a possible closer relationship of the three taxa. Utricularia amotape-huancabambensis, however, is generally much taller than $U$. praetermissa and detailed flower and leaf morphology differ as does their distribution.

The other two members of section Orchidioides present in Peru, U. jamesoniana and $U$. asplundii, show more affinities to each other (e.g. tri-partite lower corolla lip; Taylor 1989) than to U. unifolia and the new species, and may be considered more distantly related. The sheer size of $U$. amotapehuancabambensis (leaves $>40 \mathrm{~cm}$ ) and especially the length of the inflorescence $(>80 \mathrm{~cm})$ with the huge, almost white flowers that can potentially reach a diameter up to $8 \mathrm{~cm}$, make this species readily apparent and unmistakable from any other species of sect. Orchidioides and in fact any other species of Utricularia. Similar plant sizes are only reached in the $U$. nelumbifolia - U. reniformis A. St.-Hil. - U. cornigera complex (= sect. Iperua sensu Taylor), but the leaf morphology and distribution (lowlands of eastern Brazil) of these taxa differ greatly.

\section{Distribution}

The new species inhabits the páramo of the sandstone rock plateaus (white sands) of the subAndean mountain range of low elevations defined as the continuation of the southern branches of the Cordillera del Condor, located in central-northern Peruvian Andes (Fig. 1). The whole area lies well inside the so-called Amotape-Huancabamba Zone (Weigend, 2002, 2004), a biodiversity hotspot that spans from the pacific coast to the slopes of the eastern Andes of southern Ecuador and large parts of northern Peru. This area is particularly rich in phytodiversity and has been retrieved as one of the centers of diversity for many plant groups (Weigend et al., 2005a; Struwe et al., 2009; Muttke et al., 2014; Böhnert \& Weigend, 2017; Deanna et al., 2018; Escobar et al., 2018). Moreover, this area is characterized by an exceptionally high percentage of (narrow) endemisms, even for plant groups that are not exclusively Andean or particularly rich in endemic taxa. This has only recently been shown for the Lentibulariaceae with the description of Pinguicula rosmarieae Casper, Bussmann \& T. Henning (Casper et al., 2020). This species is narrowly endemic to the very moist eastern Andes in the department San Martín in north Peru, whereas most other species of this genus are rather widespread. The same seems true for the new Utricularia species described here. Whilst all closely allied taxa show a considerable distributional range, U. amotape-huancabambensis is so far known only from two nearby populations. Although it cannot be ruled out that the true range of the species is much larger than initially assumed, it seems unlikely that such a striking species had been overlooked in a much wider area. Another similarity to the situation observed in Pinguicula L. in the Amotape-Huancabamba Zone is the fact that the narrowly endemic taxon occurs sympatric with a widespread related species and both are separated by contrasting habitat requirements only. 


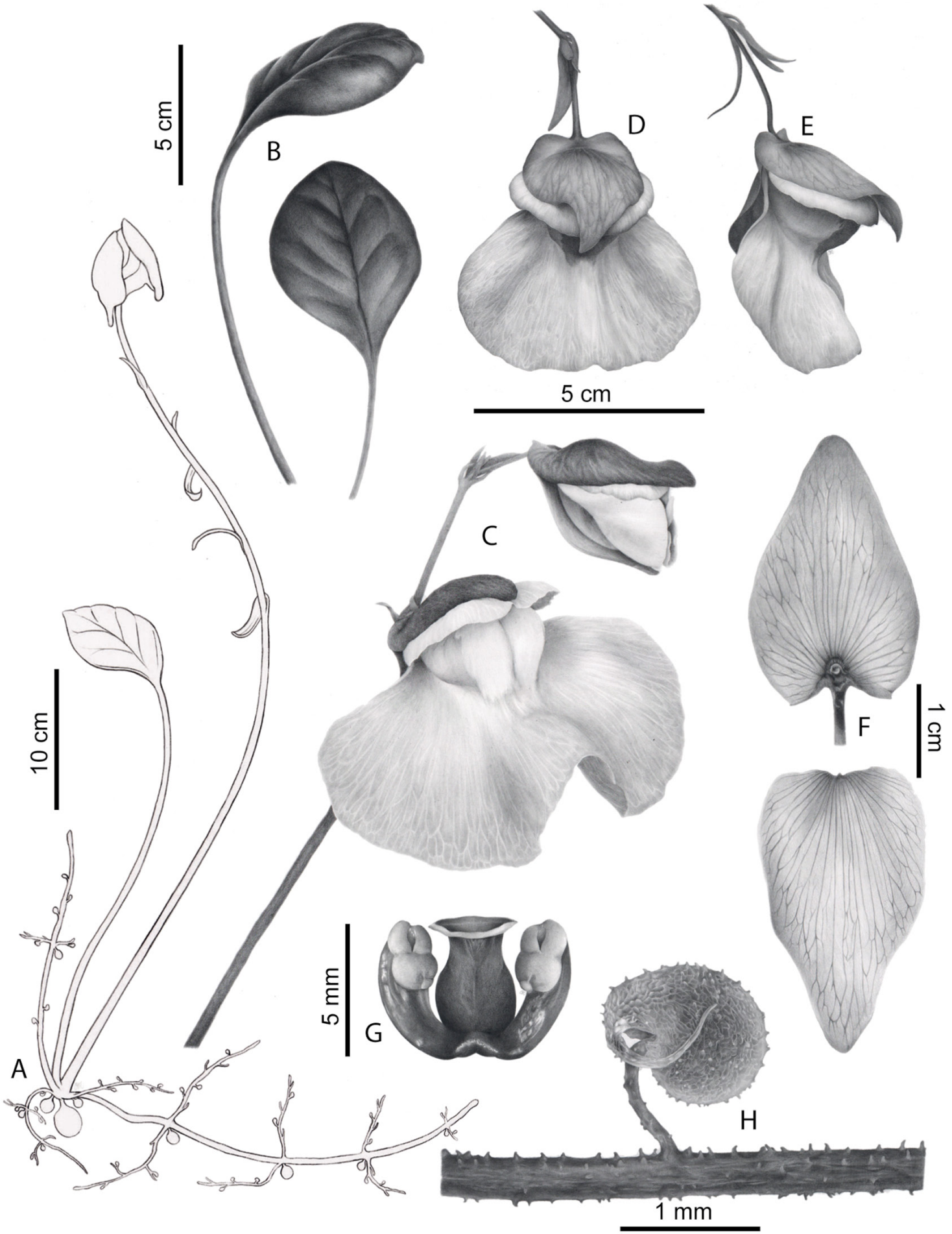

Fig. 4. Utricularia amotape-huancabambensis. A, habit. B, leaves. C, inflorescence. D, flower, frontal view. E, flower, lateral view. F, calyx. G, stamen and pistil. H, utricle. Drawing prepared by Olivia Mendoza. 
In Pinguicula, the newly described $P$. rosmarieae is only found in open, permanently wet situations, whereas sympatric $P$. calyptrata Kunth is often found in the undergrowth in shrubby grasslands without constant water flow (Casper et al., 2020). In Utricularia, a similar situation can be observed, with $U$. amotape-huancabambensis preferring drier sites than sympatric $U$. unifolia.

\section{Habitat}

Utricularia amotape-huancabambensis has been found in two habitat types, both dominated by the characteristic short-growth sclerophyllous vegetation typical for páramo habitats. At the type locality, the species inhabits a specific micro habitat niche hidden within the generally drier area. This landscape is mostly dominated by small shrubs and grasses with full sun exposure from late morning to late afternoon. Utricularia amotapehuancabambensis is extremely common here whereas $U$. unifolia is absent and this could be due to the extreme abundance of Sphagnum at this site. The second locality consists of a rock wall seepage surrounded by dense humid cloud forest. The site receives full sun exposure from midday to $\mathrm{mid} /$ late afternoon. The majority of the rock wall face is covered by a constant seepage of water, however, the extremities of this site are drier due to the lack of water seepage. Utricularia unifolia dominates this locality within the seepage areas, whereas $U$. amotape-huancabambensis is almost absent in the seepage areas and prefers the slightly drier sites of the extremities of this microhabitat. Sphagnum (L.) is present in this site, but with low population density and $U$. amotape-huancabambensis seems to almost exclusivelyprefertheseareas whereSphagnum occurs (Fig. $3 \mathrm{I}, \mathrm{J}$ ), whereas U. unifolia tends to prefer situations where Sphagnum is not present. The lack of Sphagnum cushions could explain the rarity of U. amotape-huancabambensis here. At this site, we have identified a natural hybrid between $U$. unifolia and the new species.

\section{Ecology}

Utricularia amotape-huancabambensis sends out very long running stolons through the Sphagnum cushions and the deteriorating vegetation on the soil surface. Rarely, it was found growing on bare rock, where the stolons had penetrated cracks in the rock surface, but these plants showed very stunted growth. Utricularia amotape-huancabambensis usually grows beneath the cover of surrounding vegetation, sending out new growing points as stolons up to $50 \mathrm{~cm}$ long and petioles up to 40 $\mathrm{cm}$ long to reach sunlight; both likely adaptations to thrive in dense, fast growing vegetation such as Sphagnum cushions. Another interesting observation in this context is that the petioles often grow in a horizontal direction away from the hillside and then gradually curve back upwards before forming a round, slightly folded leaf, giving the appearance of an almost upside down growth habit (Fig. 3 A, I- J). This growth habit is very unusual and has not been reported for U. unifolia or other taxa of section Orchidioides.

\section{Phenology}

Similar to the related Andean species, the plants likely flower throughout most of the year. However, the sites have been visited only in March and December, during the rainy season and flowering plants could be observed at both occasions. It is most likely that they at least flower throughout all months of the rainy season (November to April) and possibly to some extent into the dry season. Fruiting individuals were scarce, indicating some seasonality with a possible flowering break during the dry season.

\section{Associated flora}

The new species was seen in association with herbaceous and shrubby vegetation: Dillandia subumbellata V.A. Funk \& H. Rob. (Asteraceae), Baccharis reticulata (Ruiz \& Pav.) Pers. (Asteraceae), Clethra sp. (Clethraceae), Weinmannia sp. (Cunoniaceae), Ericaceae, Symbolanthus sp. (Gentianaceae), Miconia sp. (Melastomataceae), Escobedia grandiflora (L. f.) Kuntze (Orobanchaceae), Elleanthus sp., Sobralia sp. (Orchidaceae), Asplundia sp. (Cyclanthaceae), Paepalanthus planifolius (Bong.) Körn. (Eriocaulaceae), Lycopodiella cernua (L.) Pic. Serm. (Lycopodiaceae), Sticherus cf. bifidus (Willd.) Ching (Gleicheniaceae), Polypodium sp. (Polypodiaceae), Frullania sp. (Frullaniaceae) and Sphagnum sp. (Sphagnaceae). Besides U. unifolia, another species of Utricularia is present in the habitat with two different forms. 
The typical form of Utricularia subulata L. could be detected at the base of the hillside (where $U$. amotape-huancabambensis is not present) in a permanently waterlogged site and its cleistogamous dwarf form (Taylor, 1989) was found growing in and amongst $U$. amotape-huancabambensis high up on the steep hillside.

\section{Hybridization}

As mentioned above, hybrid individuals were found in one of the two known populations of $U$. amotape-huancabambensis. At this locality, $U$. unifolia grows syntopic and it is not surprising that crosses between the two closely related species occur. There are a number of successful hybridizations reported from cultivated species of Utricularia in general and sect. Orchidioides in particular (Studnička, 2005, 2006). Natural hybrids, however, have so far not been reported for members of the section and generally seem rather rare in the whole genus (Taylor, 1989). However, hybridization is common in other Andean plant groups and likely plays an important role in speciation processes, especially in younger lineages (Ackermann et al., 2008). The assumption that the recently described $U$. cornigera is in fact a natural hybrid between $U$. nelumbifolia and $U$. reniformis (Fleischmann, 2012) was later refuted with interbreeding experiments (Studnička, 2013, 2015), which were subsequently supported by molecular data (Rodrigues et al., 2017). The situation observed at the sympatric populations of $U$. amotape-huancabambensis and U. unifolia, however, also seems more complex than initially thought. At first glance, the striking new species clearly can be differentiated from $U$. unifolia and the more or less intermediate hybrid individuals (Fig. 2C-F, 3 E), based on morphological divergence and spatial separation. Upon closer inspection, especially after subsequent comparisons from observations of the putative "typical" plants of $U$. unifolia in the wild and in herbarium collections, it becomes apparent that this widespread and locally common species not only looks different from the plants categorized as hybrids, but that the majority of $U$. unifolia at this site differ to some extent and do not fit the morphological spectrum of $U$. unifolia as currently circumscribed. Whilst the superficial flower and leaf morphology clearly is that of $U$. unifolia, a large percentage of plants found at the site are more robust, with many plants being generally larger than in any other $U$. unifolia population seen so far, both in situ and in herbarium collections. Since the divergence observed is a continuum with a fluent transition to the more obvious hybrid individuals, one could speculate that after a hybridization event upon a secondary contact, the hybrid offspring seems to have a competitive advantage and is slowly displacing most of the typical $U$. unifolia. Both observations, a more robust habit and an increased competitiveness could be explained with the heterosis effect (Grant, 1975). However, it seems quite clear that the continuum in morphological similarity is skewed towards $U$. unifolia and so seems the repression process. The hybrid individuals can easily be distinguished from $U$. amotape-huancabambensis, whilst the variability in the other direction is more even, and only a low percentage of "pure" $U$. unifolia could be found at this spot. A closer examination applying molecular techniques of population genetics is strongly encouraged. The recently recognized collection from Ecuador (see Additional specimens examined) further underscores the need for strengthening the scientific exploration efforts in this part of the Amotape-Huancabamba Zone to better understand the actual distribution of the new species and the species boundaries to its closest relatives $U$. unifolia and $U$. endresii whose populations apparently overlap in that area.

\section{Preliminary conservation status}

The two known populations of the new species are small and scattered throughout its distributional range. The type locality has a size of approximately $50 \times 50 \mathrm{~m}$ and the second known population inhabits an area of ca. $100 \times 200 \mathrm{~m}$. The number of plants is difficult to assess due to the topology of the sites, but it is estimated to be a few hundred individuals. Anthropogenic pressure on the remaining vulnerable Andean habitats is constantly growing: agriculture, mining activities, and urban sprawl (Weigend et al., 2005b, 2006; Henning et al., 2019). Moreover, the impact of climate change shows increasing negative effects in that region. Changing temperature and precipitations regimes have led to severe wildfires that destroyed numerous forest remnants (Mutke et al., 2017). 
The fact that this striking species has not been collected earlier suggests that it is indeed restricted to a number of small, scattered (relic) populations. Hence the species is even more threatened by any potential impact of human interference. Moreover, since its ecological niche seems to be very narrow, in particular in terms of moisture requirements, the negative effects of climate change might be the most immediate threat to the populations as already reported for many other carnivorous plants associated with moist habitats (Cross et al., 2020). Due to the very few collections made so far in this generally under-collected area, one might consider a categorization of this taxon as Data Deficient (DD) according to the IUCN guidelines (2019). However, in the light of the aforementioned observations and assessments, $U$. amotapehuancabambensis is a very rare, narrowly endemic species occupying a highly specific ecological niche within a region severely threatened by climate change. The province of Bongará and surrounding areas have been comparatively well sampled which is substantiated by the fact that related species of Utricularia have been collected here repeatedly. It is very unlikely that vast populations of $U$. amotape-huancabambensis have been overlooked, otherwise this striking taxon would have been described earlier or would at least be documented in the local herbaria.
Utricularia amotape-huancabambensis might already be at the brink of extinction and is therefore considered Critically Endangered (CR) based on the criteria $\mathrm{A} 3, \mathrm{~B} 1$ and $\mathrm{B} 2$. To prevent at least additional pressure by poaching of this potentially highly sought after carnivorous plant for the illegal international trade (Cross et al., 2020), we keep the exact locality information confidential in this paper.

\section{Additional specimens examined}

Paratype: PERU. Amazonas. Bongará, pajonales de arena blanca, hierba unifolia con bulbos transparentes y rizomas entre los musgos, con flores color blanco con dos líneas amarillas en el centro, 2200 m s.m., 06-III-2020, J. P. Allen 3 (HUT-60722).

Utricularia cf. amotape-huancabambensis: ECUADOR. Zamora Chinchipe. 2000-2440 m s.m., 26-VI-2014, Pérez et al. 7423 (QCA-235884!). The leaves and flowers of this specimen show a similar morphology, in particular to the plants we consider to be hybrids with $U$. unifolia, i.e. intermediate in size (inflorescences $40-45 \mathrm{~cm}$ ), ovate leaves and palelavender to violet corolla.

PERU. Amazonas. Condorcanqui, Cordillera del Condor, 2160 m s.m., 31-VII-1994, Beltran 1519 (F2177976!, USM!). The collection at F shows a single inflorescence with only the calyx lobes left and without any other organs. It is added here due to the suspicious size of the flower stalk and the suitable collection area.

\section{Key to the Andean and selected similar taxa of Utricularia sect. Orchidioides (modified from Taylor 1989)}

3. Corolla upper lip longer than broad, narrower than, or only slightly wider than the calyx ................................... 5

4(3). Corolla densely covered with gland-tipped hairs

5(3). Corolla upper lip shorter and narrower than the calyx, apex of spur curved upwards

5. Corolla upper lip wider and longer than the calyx, apex of spur curved downwards

6(5). Scales and bracts less than $8 \mathrm{~mm}$, leaves narrowly elliptic with petiole less than $20 \mathrm{~cm}$ long. Central America .....

U. praetermissa

6. Scales and bracts 3-4 cm long; leaves broadly ovate to rounded, with petiole more than $20 \mathrm{~cm}$ long. North Peru $\ldots .$. 


\section{ACKNOWLEDGEMENTS}

We like to express our sincere gratitude to the curators and staff of the herbaria listed above. Special thanks are due to Alvaro Javier Pérez (Quito) who generously shared photos and data of potentially interesting collections from Ecuador with us. Olivia Mendoza (https://www. oliviamendozaillustration.com/) is gratefully thanked for the preparation of the excellent illustration. Valuable comments of an anonymous reviewer and the editor helped to improve an earlier version of the manuscript.

\section{BIBLIOGRAPHY}

Ackermann, M.; M. Achatz \& M. Weigend. 2008. Hybridization and crossability in Caiophora (Loasaceae subfam. Loasoideae): are interfertile species and inbred populations result of a recent radiation? American Journal of Botany 95 (9): 1109-1121.

Böhnert, T. \& M. Weigend. 2017. Brunellia (Brunelliaceae) in Peru - distribution, a new species and a key. Phytotaxa 329 (2): 101-113. DOI: https://doi.org/10.11646/phytotaxa.329.2.1

Casper, S. J.; R. W. Bussmann \& T. Henning. 2020. Pinguicula rosmarieae Casper, Bussmann \& T. Henning (Lentibulariaceae), a new butterwort from the AmotapeHuancabamba Zone (northern Peru). PhytoKeys 140: 107123. DOI: https://doi.org/10.3897/phytokeys.@.49529

Cheng, Z.; Q. Fang, F. Wang \& C. L. Long. 2021. Utricularia lihengiae (Lentibulariaceae), a new species from Northwest Yunnan, China. PhytoKeys 177: 17-24. DOI: https://doi. org/10.3897/phytokeys.177.63346

Cross, A. T.; T. A. Krueger, P. M. Gonella, A. S. Robinson \& A. S. Fleischmann. 2020. Conservation of carnivorous plants in the age of extinction. Global Ecology and Conservation 24: e01272. DOI: https://doi.org/10.1016/j.gecco.2020.e01272

Deanna, R.; G. E. Barboza \& C. Carrizo-García. 2018. Phylogenetic relationships of Deprea: New insights into the evolutionary history of physaloid groups. Molecular Phylogenetics and Evolution 119: 71-80. DOI: https://doi. org/10.016/j.ympev.2017.11.001

Escobar, S.; J. C. Pintaud, H. Balslev, R. Bernal, M. Moraes Ramírez, B. Millán \& R. Montúfar. 2018. Genetic structuring in a Neotropical palm analyzed through an Andean orogenesis-scenario. Ecology and Evolution 8: 8030-8042. DOI: https://doi.org/10.1002/ece3.4216

Fleischmann, A. 2012. The new Utricularia species described since Peter Taylor's monograph. Carnivorous Plant Newsletter 41: 67-76.
Fleischmann, A. 2015. Taxonomic Utricularia news. Carnivorous Plant Newsletter 44: 13-16.

Gómez-Laurito, J. 2005. Utricularia uxoris (Lentibulariaceae), una nueva especie costarricense de la sect. Orchidioides. Lankesteriana 5 (2): 137-139.

Gonella, P. M.; R. G. Barbosa-Silva, A. S. Fleischmann, D. C. Zappi, P. C. Baleeiro \& C. O. Andrino. 2020. Hidden biodiversity of Amazonian white-sand ecosystems: two distinctive new species of Utricularia (Lentibulariaceae) from Pará, Brazil. PhytoKeys 169: 75-98. DOI: https://doi. org/10.3897/phytokeys. 169.5766

Grant, V. 1975. Genetics of flowering plants. New York: Columbia University Press.

Henning, T.; R. H. Acuña-Castillo, E. F. Rodríguez-Rodríguez, L. F. Garcia-Llatas \& M. Weigend. 2019. A new striking and critically endangered species of Nasa (Loasaceae, Cornales) from North Peru. PhytoKeys 121: 13-28. DOI: https://doi. org/10.3897/phytokeys.121.33927

IUCN. 2019. Guidelines for Using the IUCN Red List Categories and Criteria. Version 14. Available at https://nc.iucnredlist. org/redlist/content/attachment_files/RedListGuidelines.pdf [accessed 28-VII-2021].

Jobson, R. W.; J. Playford, K. M. Cameron \& V. A. Albert. 2003. Molecular phylogenetics of Lentibulariaceae inferred from plastid rps16 intron and trnL-F DNA sequences: implications for character evolution and biogeography. Systematic Botany 28: 157-171.

Karger, D. N.; M. Kessler, M. Lehnert \& W. Jetz. 2021. Limited protection and ongoing loss of tropical cloud forest biodiversity and ecosystems worldwide. Nature Ecology and Evolution. DOI: https://doi.org/10.1038/s41559-021-01450-y

Müller, K. \& T. Borsch. 2005. Phylogenetics of Utricularia (Lentibulariaceae) and molecular evolution of the $\operatorname{trnK}$ intron in a lineage with high substitutional rates. Plant Systematics and Evolution 250: 39-67. DOI: https://doi. org/10.1007/s00606-004-0221-1

Mutke, J.; R. Jakobs, K. Meyer, T. Henning \& M. Weigend. 2014. Diversity patterns of selected Andean plant groups correspond to topography and habitat dynamics, not orogeny. Frontiers in Genetics 5: 351. DOI: https://doi.org/10.3389/fgene.2014.00351

Mutke, J.; T. Böhnert \& M. Weigend. 2017. Save last cloud forests in western Andes. Nature 541 (7636): 157. DOI: https://doi.org/10.1038/541157e

Rodrigues, F. G.; N. F. Marulanda, S. R. Silva, B. J. Plachno, L. Adamec \& V. F. O. Miranda. 2017. Phylogeny of the 'orchidlike' bladderworts (gen. Utricularia sect. Orchidioides and Iperua: Lentibulariaceae) with remarks on the stolon-tuber system. Annals of Botany 120 (5): 709-723. DOI: https://doi. org/10.1093/aob/mcx056 


\section{T. HENNING ET AL. A new species of Utricularia sect. Orchidioides}

Struwe, L.; S. Haag, E. Heiberg \& J. R. Grant. 2009. Andean speciation and vicariance in neotropical Macrocarpaea (Gentianaceae-Helieae). Annals of the Missouri Botanical Garden 96 (3): 450-469. DOI: https://doi. org/10.3417/200840

Studnička, M. 2005. New cultivar: Utricularia 'Jitka'. Carnivorous Plant Newsletter 34: 27-28.

Studnička, M. 2006. Unexpected hybrids of spectacular bladderwort species. Carnivorous Plant Newsletter 35: 59-61.

Studnička, M. 2009. Brazilian bladderwort Utricularia reniformis is a blend of two species. Thaiszia - Journal of Botany 19: 131-143.

Studnička, M. 2013. Brief information about the species status of Utricularia cornigera Studnička. Carnivorous Plant Newsletter 42: 15-80.

Studnička, M. 2015. Second brief piece of information about the species status of Utricularia cornigera Studnička. Carnivorous Plant Newsletter 44: 204-206.

Taylor, P. 1986. New Taxa in Utricularia (Lentibulariaceae). Kew Bulletin 41 (1): 1-18.

Taylor, P. 1989. The genus Utricularia - a taxonomic monograph. Kew Bulletin Additional Ser. XIV. Kew: Royal Botanical Gardens.

Thiers, B. 2021. Index Herbariorum: A Global Directory of Public Herbaria and Associated Staff. New York Botanical Garden's Virtual Herbarium. https://sweetgum.nybg.org/ science/ih/
Weigend, M. 2002. Observations on the Biogeography of the AmotapeHuancabamba Zone in northern Peru, in K. Young, U. C. Ulloa, J. L. Luteyn \& S. Knapp (eds.), Plant Evolution and Endemism in Andean South America. Botanical Review 68 (1): 38-54.

Weigend, M. 2004. Additional observations on the biogeography of the Amotape-Huancabamba Zone in Northern Peru: Defining the South-Eastern limits. Revista Peruana de Biología 11 (2): 127-134.

Weigend, M.; A. Cano \& E. F. Rodríguez-Rodríguez. 2005a. New species and new records of the flora in the AmotapeHuancabamba Zone: Endemics and biogeographic limits. Revista Peruana de Biología 12 (2): 249-274.

Weigend, M.; E. F. Rodríguez-Rodríguez \& C. Arana. 2005 b. The relict forests of northwest Peru and southwest Ecuador. Revista Peruana de Biología 12: 185-194.

Weigend, M.; N. Dostert \& E. F. Rodríguez-Rodríguez. 2006. Bosques relictos de los Andes peruanos: Perspectivas económicas, in M. Moraes, B. Øllgaard, L. P. Kvist, F. Borchsenius \& H. Balslev (eds.), Botánica Económica de los Andes Centrales. La Paz: Universidad Mayor de San Andrés.

GBIF data downloads

U. unifolia: GBIF.org (28 July 2021) GBIF Occurrence Download https://doi.org/10.15468/d1.2ch9em

U. jamesoniana: GBIF.org (28 July 2021) GBIF Occurrence Download https://doi.org/10.15468/d1.jwcsxx

U. asplundii: GBIF.org (28 July 2021) GBIF Occurrence Download https://doi.org/10.15468/dl.x4pjv4 